\title{
Randomised Comparison of the Effect of $0.2 \%$ Glyceryl Trinitrate and $0.5 \%$ Topical Nifedipine in Acute Anal Fissure Treatment
}

\author{
Akut Anal Fissür Tedavisinde \%0,2 Gliseril Trinitrat ile \%0,5 Topikal \\ Nifedipinin Etkilerinin Randomize Karşılaştırılması
}

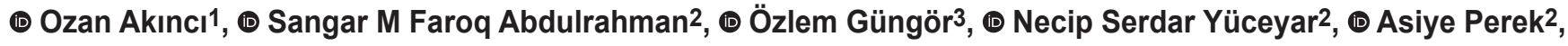 \\ (1) Murat Süphan Ertürk2 \\ 'Hakkari State Hospital, Clinic of General Surgery, Hakkari, Turkey \\ 2İstanbul University-Cerrahpaşa, Cerrahpaşa Faculty of Medicine, Department of General Surgery, İstanbul, Turkey \\ ${ }^{3}$ Hakkari State Hospital, Clinic of Radiology, Hakkari, Turkey
}

\section{IIIIIIII ABSTRACT}

Aim: This prospective clinical trial study aimed to compare the effects of $0.2 \%$ glyceryl trinitrate (GTN) and $0.5 \%$ topical nifedipine (ND) on acute anal fissure treatment and recurrence prevention.

Method: The study included 100 patients who were diagnosed with acute anal fissure and randomly divided into two groups: the $0.2 \%$ GTN and $0.5 \%$ topical ND groups. On the first visit, age, sex, constipation, pain duration after defaecation and visual analogue scale (VAS) score were recorded. After 21 days of treatment, symptomatic relief levels, healing, VAS score and drug side effects were recorded.

Results: The female/male ratios for the GTN and ND groups were 50\%/50\% and 54\%/46\%, respectively. The mean ages were 29.3 and 30.7 years for the GTN and ND groups, respectively. After treatment, the excellent symptomatic relief level in the ND group (56\%) was higher than in the GTN group (22\%; $\mathrm{p}=0.005)$. Post-treatment mean VAS score was significantly lower in the ND group than in the GTN group ( $<<0.001)$. The mean decrease of VAS score in the ND group between pre-treatment and post-treatment was significantly higher than in the GTN group ( $\mathrm{p}=0.001$ ). The healing rate in the ND group (86\%) was higher than in the GTN group (64\%; $\mathrm{p}=0.011)$. The drug side effect rate was significantly lower in the ND group (4\%) than in the GTN group (22\%; $=0.007$ ). The recurrence rates were 38\% in the GTN group and 18\% in the ND group ( $\mathrm{p}=0.026$ ).

Conclusion: Our study shows that both GTN and topical ND have favourable effects on anal fissure treatment. However, $0.5 \%$ topical ND is superior to $0.2 \%$ GTN for treating anal fissure in terms of symptomatic relief, pain score, healing, drug side effects and recurrence rate.

Keywords: Acute anal fissure, glyceryl trinitrate, nifedipine

\section{||||||||| ÖZ}

Amaç: $\mathrm{Bu}$ prospektif klinik çalışma \%0,2 gliseril trinitrat (GTN) ve \%0,5 topikal nifedipinin (ND) akut anal fissür tedavisinde ve rekürrensin önlenmesindeki etkilerini karşılaştırmayı amaçlamaktadır.

Yöntem: Çalışmaya akut anal fissür tanılı 100 hasta dahil edildi ve hastalar \%0,2 GTN ve \%0,5 ND olmak üzere rastgele iki gruba ayrıldı. İlk muayenede yaş, cinsiyet, konstipasyon, defekasyon sonrası ağrı süresi ve visual analog skala (VAS) skorları kaydedildi. Yirmi bir günlük tedavinin ardından semptomatik rahatlama düzeyleri, iyileşme, VAS skoru ve ilaç yan etkileri kaydedildi.

Bulgular: GTN ve ND gruplarında kadın/erkek oranı sırasıyla \%50/50 ve \%54/46 idi. Ortalama yaş GTN ve ND gruplarında sırasıyla 29,3 ve 30,7 idi. Tedavi sonrası mükemmel semptomatik rahatlama düzeyi ND grubunda (\%56) GTN grubuna (\%22) göre daha yüksekti ( $\mathrm{p}=0,005)$. Tedavi sonrası VAS skoru ND grubunda GTN grubuna göre anlamlı ölçüde daha düşüktü ( $p<0,001$ ). Tedavi öncesi ve sonrası VAS skoru düşüşü ortalaması ND

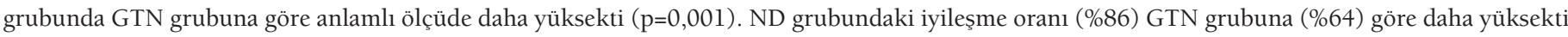
$(\mathrm{p}=0,011)$. İlaç yan etkileri oranı ND grubunda (\%4) GTN grubuna (\%22) göre anlamlı ölçüde daha düşktü ( $\mathrm{p}=0,007)$. GTN grubunun rekürrens oranı $\% 38$, ND grubunun ise $\% 18$ idi $(\mathrm{p}=0,026)$. 
Sonuç: Çalışmamız hem GTN hem de topikal ND'nin akut anal fissür tedavisinde olumlu etkileri olduğunu göstermektedir. Bununla birlikte, akut anal fissür tedavisinde \%0,5 topikal ND; semptomatik rahatlama, ağrı skoru, iyileşme, ilaç yan etkileri ve rekürrens açısından \%0,2 GTN'den üstündür.

Anahtar Kelimeler: Akut anal fissür, gliseril trinitrat, topikal nifedipine

\section{Introduction}

Anal fissures are painful tears that occur in stratified squamous epithelium of the anal canal. The exact etiology is unclear, however, it's believed that sphincter spasm which occurs due to traumatic injury of hard stool passage, leads to an increase in anal canal pressure and local ischemia of the anal mucosa. ${ }^{1,2}$ The most common symptoms are pain, spasm and rectal bleeding. Acute anal fissures are short-term shallow lesions, while chronic anal fissures are deep and persisting lesions lasting more than 6-8 week. ${ }^{3}$ The vast majority of the anal fissures are localized in the posterior midline. ${ }^{4}$ The aim of the treatment is to decrease internal anal sphincter resting pressure and to improve blood flow again in the ischemic area. The majority of anal fissures resolve without surgical intervention. Traditional surgical approaches are anal dilatation and lateral internal sphincterotomy but may result with anal incontinence. ${ }^{5}$ In addition to this important complication, the workload and cost of surgical intervention lead to searching alternative management methods. Recent literature analysis acknowledges that medical treatment should be the firstline of therapy, and surgical treatment should be planned in case of recurrence and medical treatment failure. ${ }^{6}$ Agents such as glyceryl trinitrate, diltiazem, nifedipine, botulinum toxin, bethanechol, and indoramin are among chemical sphincterotomy options. ${ }^{7}$ There is still debate on which medical agent is superior in anal fissure healing and recurrence prevention. Glyceryl trinitrate, a nitric oxide donor, has been shown by multiple studies to be effective in the treatment of anal fissure by lowering anal sphincter resting pressure. ${ }^{6,8,9}$ Nifedipine which is a calcium channel blocker decreases anal sphincter tone through blocking voltage-gated and non-voltage-gated adrenergic receptoroperated calcium channels in smooth muscle membrane of vessels. ${ }^{10}$

The aim of this study is to compare the effect of $0.2 \%$ glyceryl trinitrate and $0.5 \%$ topical nifedipine on acute anal fissure treatment and recurrence prevention.

\section{Materials and Methods}

This prospective study included a total of 100 patients who were diagnosed with acute anal fissure at Hakkari State Hospital General Surgery Clinic between April 2019 and February 2020. Approval has been obtained from local ethics committee for the study (approval no: 02/20.11.2019). The patients were informed in detail about the study and written consents were obtained. Patients over 18 years of age diagnosed with an acute anal fissure for the first time were included in the study. Patients with chronic anal fissure, inflammatory bowel disease, hemorrhoid, tuberculosis, anal cancer, history of anal surgery, pregnant and lactating, under the age of 18 and patients who didn't want to enroll in the study were excluded.

Patients were randomly separated into two groups, $0.2 \%$ glyceryl trinitrate (GTN) group, and $0.5 \%$ topical nifedipine (ND) group. At the first visit age, sex, presence of constipation, difficulty in defecation, pain duration after defecation, amount of fluid consumed daily, anatomic localization of the fissure and visual analog scale (VAS) score ranging from 0 to 10 for pain assessment were recorded. Roma-4 criteria was used as a reference for diagnosis of constipation. ${ }^{11}$ While questioning the daily fluid consumption amounts of the patients, 0.5-1.0-1.5-2.02.5-3.0-3.5-4.0 liter options are presented to them and the approximate amount of fluid consumed by the patients is recorded in this way. $0.2 \%$ glyceryl trinitrate was applied to the GTN group and $0.5 \%$ topical nifedipine to the ND group twice daily for twenty-one days. Patients were informed to apply the ointment as much as chickpea grain around the anus and $1 \mathrm{~cm}$ within the anal canal. $0.2 \%$ glyceryl trinitrate and $0.5 \%$ nifedipine ointments were prepared by a pharmacist because neither of the ointments is available by there trade names in Turkey. Powder forms of 0.5 grams nifedipine capsule active ingredient and 0.2 grams of glyceryl trinitrate were mixed with 100 grams of petroleum jelly and placed in 100-gram ointment boxes. Ointments were obtained from the pharmacy with a magistral prescription. All patients of both groups were prescribed stool softeners and informed to consume a fiber-rich diet. All patients were advised usage of warm sitz bath for 10-15 minutes, 2-3 times daily. No analgesics were prescribed.

Patients were assessed after twenty-one days of treatment. In this second assessment, symptomatic relief levels, healing, VAS scores after treatment and side effects of drugs (such as headache, perineal irritation) were recorded. Symptomatic relief levels were assessed in a 4 level model as "excellent, good, moderate and nil". Patients who were found to have fissure again in the control examination were given additional therapy with the same drug and dosage for two more weeks. Rectoscopy was done for all of the patients 
after symptomatic relief and other pathologies were ruled out. None of the patients had undergone rectoscopy before treatment. All cases were re-examined for recurrence three months after treatment.

\section{Statistical Analysis}

The statistical analysis of the findings obtained from the study was performed with the SPSS version 17.0 program. Suitability of variables to normal distribution was assessed by histogram graphics and Kolmogorov-Smirnov test. While presenting descriptive analyzes, mean, standard deviation and median values were used. Pearson chi-square and Fischer's exact tests were used in $2 \times 2$ tables. MannWhitney $\mathrm{U}$ test was used for the evaluation of not normally distributed (non-parametric) variables between groups. A p value of $<0.05$ was considered statistically significant.

\section{Results}

There were 50 patients in each group, the female/male ratio for the GTN group was $25 / 25$ (50/50\%), while it was $27 / 23$ (54/46\%) for the ND group. The mean age was 29.3 for the GTN group and 30.7 for the ND group. There was no statistically significant difference between the groups in terms of age and sex distribution (Table 1).

When the symptoms of the patients were evaluated in both groups, the most common symptom was pain (100\%), then bleeding, and itching respectively (Table 2 ). Constipation was seen in $62 \%$ of GTN group patients, and $68 \%$ of the ND group. 12 (24\%) patients in the GTN group and $14(28 \%)$ in the ND group reported that they always had difficult defecation. The average pain duration after defecation was observed to be 3.25 hours for the GTN group and 3.30

Table 1. Demographic characteristics of patients participating in the study according to the groups

\begin{tabular}{|c|c|c|c|c|c|c|c|c|}
\hline \multirow{2}{*}{$\mathbf{n}$} & & \multicolumn{2}{|l|}{ GTN } & \multicolumn{2}{|l|}{ ND } & \multicolumn{2}{|l|}{ Total } & \multirow{2}{*}{$\mathrm{p}$} \\
\hline & & $\%$ & $\mathrm{n}$ & $\%$ & $\mathrm{n}$ & $\%$ & & \\
\hline \multirow{2}{*}{ Gender } & Male & 25 & 50.00 & 27 & 54.00 & 52 & 52.00 & \multirow{2}{*}{$0.689^{a}$} \\
\hline & Female & 25 & 50.00 & 23 & 46.00 & 48 & 48.00 & \\
\hline Age (years) & & $29.36 \pm 8.97$ & 27.00 & $30.78 \pm 8.55$ & 29.00 & $30.07 \pm 8.75$ & 28.00 & $0.288^{\mathrm{b}}$ \\
\hline
\end{tabular}

${ }^{\mathrm{a}}$ Chi-square test, ${ }^{\mathrm{b}}$ Mann-Whitney U test, GTN: Glyceryl trinitrate, ND: Nifedipine

Table 2. Comparison of symptoms, constipation, defaecation difficulty and fissure localisation of patients on the first presentation between the groups

\begin{tabular}{|c|c|c|c|c|c|c|}
\hline \multirow{2}{*}{$\mathbf{n}$} & & \multicolumn{2}{|c|}{ GTN } & \multicolumn{2}{|l|}{ ND } & \multirow{2}{*}{$\mathrm{p}$} \\
\hline & & $\%$ & $\mathrm{n}$ & $\%$ & & \\
\hline \multirow{2}{*}{ Pain } & No & 0 & 0 & 0 & 0 & \multirow{2}{*}{$* * *$} \\
\hline & Yes & 50 & 100.00 & 50 & 100.00 & \\
\hline \multirow{2}{*}{ Bleeding } & No & 17 & 34.00 & 20 & 40.00 & \multirow{2}{*}{0.534} \\
\hline & Yes & 33 & 66.00 & 30 & 60.00 & \\
\hline \multirow{2}{*}{ Itching } & No & 38 & 76.00 & 37 & 74.00 & \multirow{2}{*}{0.817} \\
\hline & Yes & 12 & 24.00 & 13 & 26.00 & \\
\hline \multirow{2}{*}{ Constipation } & No & 19 & 38.00 & 16 & 32.00 & \multirow{2}{*}{0.529} \\
\hline & Yes & 31 & 62.00 & 34 & 68.00 & \\
\hline \multirow{4}{*}{$\begin{array}{l}\text { Difficulty in } \\
\text { defaecation }\end{array}$} & Never & 1 & 2.00 & 2 & 4.00 & \multirow{4}{*}{0.885} \\
\hline & Sometimes & 18 & 36.00 & 16 & 32.00 & \\
\hline & Often & 19 & 38.00 & 18 & 36.00 & \\
\hline & Always & 12 & 24.00 & 14 & 28.00 & \\
\hline \multirow{2}{*}{ Location } & Anterior midline & 15 & 30.00 & 13 & 26.00 & \multirow{2}{*}{0.656} \\
\hline & Posterior midline & 35 & 70.00 & 37 & 74.00 & \\
\hline
\end{tabular}

Chi-square test, GTN: Glyceryl trinitrate, ND: Nifedipine 
hours for the ND group. When daily fluid consumption was questioned, it was found that those in the GTN group consumed 1.55 liters/day and those in the ND group consumed 1.57 liters/day (Table 3). Fissures were found to be located in the posterior midline in $70 \%$ of the GTN group and $74 \%$ of the ND group. There was no statistically significant difference between the two groups in terms of symptoms, constipation, frequency of difficult defecation, pain duration after defecation, daily fluid consumption, and localization of the fissure (Table 2,3).

When the patients were seen and examined after 21 days of treatment the proportion of patients with excellent symptomatic relief in the ND group was $56 \%$ and $22 \%$ in the GTN group. While the good and moderate symptomatic relief rates in the ND group were $24 \%$ and $14 \%$, respectively, these rates were $50 \%$ and $22 \%$ in the GTN group. Excellent symptomatic relief was significantly higher in ND group than in GTN group ( $\mathrm{p}=0.005$ ) (Table 4). No significant difference was seen between the groups when the pre- treatment mean VAS score was evaluated $(\mathrm{p}=0.273)$. Posttreatment mean VAS score was significantly lower in the ND group than the GTN group $(\mathrm{p}<0.001)$. The mean decrease of VAS score in the ND group between pre and post-treatment was $6.14 \pm 2.07$, while it was $5.02 \pm 1.92$ in the GTN group and the decrease of VAS score in ND group was significantly higher than GTN group (p:0.001) (Table 4).

When the patients were seen and examined after 21 days of treatment, the healing rate in the ND group (86\%) was higher than the GTN group (64\%) ( $\mathrm{p}=0.011)$. Headache was seen in $11(22 \%)$ patients of the GTN group, $2(4 \%)$ patients in the ND group experienced local irritation. None of the patients interrupted the treatment due to the side effects of the drugs. The drug side effect rate was significantly lower in the ND group compared to GTN group ( $\mathrm{p}=0.007)$.

Evaluation after 3 months of follow-up showed that the recurrence rate was 38\% in the GTN group, $18 \%$ in the ND group, and the recurrence rate in the ND group was statistically significantly lower $(\mathrm{p}=0.026)$.

Table 3. Comparison of the pain duration after defaecation and amount of fluid consumed daily between the groups

$\begin{array}{llllllll} & \text { GTN } & & & & \text { ND } & & \\ & \text { Mean } & \text { SD } & \text { Median } & \text { Mean } & \text { SD } & \text { Median } & \text { p } \\ \text { Pain duration after defaecation (h) } & 3.25 & \pm 2.47 & 2.00 & 3.30 & \pm 2.44 & 2.50 & 0.967 \\ \text { Amount of fluid consumed daily (L) } & 1.57 & \pm 0.83 & 1.25 & 1.55 & \pm 0.80 & 1.50 & 0.928\end{array}$

Mann-Whitney U test, SD: Standard deviation, GTN: Glyceryl trinitrate, ND: Nifedipine

Table 4. Comparison of clinical characteristics of the groups after treatment

\begin{tabular}{|c|c|c|c|c|c|c|}
\hline \multirow{2}{*}{ n } & & \multicolumn{2}{|c|}{ GTN } & \multicolumn{2}{|l|}{ ND } & \multirow{2}{*}{$\mathrm{p}$} \\
\hline & & $\%$ & $\mathrm{n}$ & $\%$ & & \\
\hline \multirow{4}{*}{ Symptomatic relief level } & Nil & 3 & 6.00 & 3 & 6.00 & \multirow{4}{*}{$0.005^{\mathrm{a}}$} \\
\hline & Moderate & 11 & 22.00 & 7 & 14.00 & \\
\hline & Good & 25 & 50.00 & 12 & 24.00 & \\
\hline & Excellent & 11 & 22.00 & 28 & 56.00 & \\
\hline \multirow{2}{*}{ Healing (21 days) } & No & 18 & 36.00 & 7 & 14.00 & \multirow{2}{*}{$0.011^{\mathrm{a}}$} \\
\hline & Yes & 32 & 64.00 & 43 & 86.00 & \\
\hline \multirow{2}{*}{ Drug side effects } & No & 39 & 78.00 & 48 & 96.00 & \multirow{2}{*}{$0.007^{\mathrm{a}}$} \\
\hline & Yes & 11 & 22.00 & 2 & 4.00 & \\
\hline \multirow{2}{*}{ Recurrence (3 months) } & No & 31 & 62.00 & 41 & 82.00 & \multirow{2}{*}{$0.026^{\mathrm{a}}$} \\
\hline & Yes & 19 & 38.00 & 9 & 18.00 & \\
\hline \multicolumn{2}{|l|}{ Pre-treatment VAS score* } & \multicolumn{2}{|c|}{$7.94 \pm 1.46$} & \multicolumn{2}{|c|}{$7.68 \pm 1.28$} & $0.273^{\mathrm{b}}$ \\
\hline \multicolumn{2}{|l|}{ Post-treatment VAS score* } & \multicolumn{2}{|c|}{$2.92 \pm 1.75$} & \multicolumn{2}{|c|}{$1.54 \pm 1.43$} & $0.001^{\mathrm{b}}$ \\
\hline \multicolumn{2}{|l|}{ Decrease of VAS score* } & \multicolumn{2}{|c|}{$5.02 \pm 1.92$} & \multicolumn{2}{|c|}{$6.14 \pm 2.07$} & $0.001^{\mathrm{b}}$ \\
\hline
\end{tabular}

${ }^{a}$ Chi-square test, ${ }^{b}$ Mann-Whitney U test, "Mean \pm standard deviation, GTN: Glyceryl trinitrate, ND: Nifedipine 


\section{Discussion}

An anal fissure is one of the most commonly seen anorectal diseases. Clinically the development of fissure is almost always due to chronic constipation or following passage of hard/difficult stool. The posterior midline is known to be more susceptible to trauma and to be torn first due to the anorectal angle and topography of the pelvic floor muscles. ${ }^{3}$ In the light of anal manometry, arteriography, and doppler findings, internal anal sphincter hypertonicity, and relative poor perfusion are believed to be two main factors in the pathogenesis of anal fissure. ${ }^{12,13,14}$ Klosterhalfen et al. ${ }^{15}$ showed that posterior commissure, where $90 \%$ of anal fissures are localized, is less perfused than the other parts of the anal canal in postmortem angiographies. For this reason, typically anal fissures are often located in the posterior midline. In the literature, it has been reported that anal fissures are located in the posterior midline at a rate of $70.5-94 \%{ }^{16,17,18}$ In $72 \%$ of the patients in our study, the fissure was located in the posterior midline, while in $28 \%$ in anterior midline. Atypical fissures are multiple, localized outside the midline, and develop secondary to diseases such as AIDS, crohn, malignancy, and tuberculosis. Patients with atypical fissures were not included in our study.

Due to surgery-related anal incontinence and other complications, there is a tendency in today's medicine from surgery towards medical modalities in the treatment of anal fissures. ${ }^{19}$ Chemical sphincterotomy is preferred as the first-line of treatment since it is non-invasive, does not require anesthesia, reversible, repeatable, applicable at home, economic, and practical. ${ }^{20,21}$ Topical GTN is the most widely used chemical agent in the treatment of anal fissures, it reduces anal sphincter tonicity by its non-adrenergic, non-cholinergic effect and its main side effect is headache which occurs in $40 \%$ of the patients. ${ }^{22}$ Besides, it also has side effects like tachyphylaxis, orthostatic hypotension, and

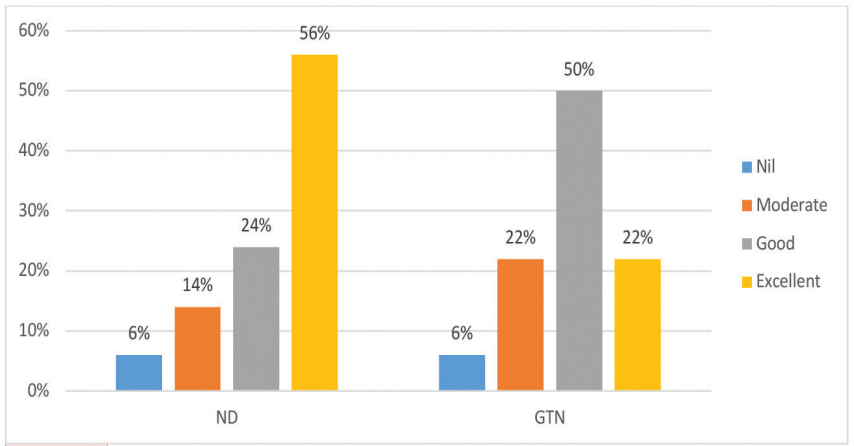

Graphic 1. Comparison of symptomatic relief levels of patients at the end of treatment between groups

GTN: Glyceryl trinitrate, ND: Nifedipine syncope. ${ }^{23}$ The high recurrence rate is another disadvantage of GTN. ${ }^{23,24}$ It has been reported that there is no significant difference between $0.4 \%$ and $0.2 \%$ GTN forms in terms of healing of anal fissure, and $0.4 \%$ GTN has a higher rate of headache. ${ }^{25,26}$ For these reasons, we preferred the $0.2 \%$ GTN form in our study.

Calcium channel blockers like nifedipine and diltiazem are successful agents in the treatment of anal fissures in both oral and topical application., ${ }^{7,10,22}$ It has been shown that topical application of nifedipine has fewer side effects and a higher healing rate compared to oral administration. ${ }^{16,27,28}$ The transport of calcium through L-type calcium channel is essential in maintaining internal anal sphincter tone, and nifedipine breaks the fissure cascade by reducing spontaneous sphincter activity through preventing intracellular access of calcium. ${ }^{29}$ Experimental studies have shown that nifedipine has also a local anti-inflammatory and a favorable effect on microcirculation. ${ }^{30,31}$

A significant decrease in the VAS score and symptomatic relief was observed in both GTN and ND group patients in our study. However, when the decrease in the VAS score rate and symptomatic relief levels were compared between the two groups, nifedipine was observed to be significantly more effective. Besides, the rate of healing in anal fissure was higher in the ND group ( $86 \%$ vs $64 \%$ ) when an anal examination was done after treatment. The healing rate in anal fissure was reported to be $94 \%$ by Perrotti et al. ${ }^{32}$ and $85 \%$ by Katsinelos et al. ${ }^{7}$ when nifedipine was used. Similar to our study, Shrestha et al. ${ }^{21}$ also showed that topical ND has a higher healing rate than GTN. In another study, it was reported that both drugs lead to a significant decrease in pain scores with no difference between the groups, but the healing rate was higher in the ND group than the GTN group. $^{33}$

When drug side effects were examined in our study, it was significantly higher in GTN group than ND group $(\mathrm{p}=0.007)$. This ratio was $40 \%$ vs $5 \%$ and $16 \%$ vs $7 \%$ in the studies of Ezri et al. ${ }^{33}$ and Shreshta et al. ${ }^{21}$, respectively, and both studies have shown that the side effects of the GTN group were significantly higher. Headache; the most important side effect of GTN reduces drug compliance and prevents the patients from taking the drug regularly and for the expected duration. For this reason, we can say that ND is more advantageous than GTN concerning both patient satisfaction and tolerance.

After chemical sphincterotomy treatment, anal canal pressure returns to pre-treatment levels and from this aspect, chemical sphincterotomy differs from surgical sphincterotomy. For this reason, chemical sphincterotomy has a higher risk of recurrence. In our study, the recurrence rate of the ND group was significantly lower than that of 
the GTN group ( $18 \%$ vs $38 \%)(p=0.026)$. Shrestha et al. ${ }^{21}$ reported similar results in their study, while two other studies reported no difference between the two drugs in terms of recurrence. . $^{33,34}$

\section{Study Limitations}

The limitations of our study were it's small number of patients, being single-centered, short follow-up period (3 months), and inability to measure anal canal resting pressure before and after treatment in the institution where the study was done.

\section{Conclusion}

Data obtained from our study shows that both glyceryl trinitrate and topical nifedipine have favorable effects on anal fissure treatment. However, topical $0.5 \%$ nifedipine is superior to $0.2 \%$ glyceryl trinitrate in the treatment of anal fissure in terms of symptomatic relief, decrease in pain score, healing, drug side effects, and recurrence. But, it is a fact that there is a need for prospective clinical studies with a larger number of patients, long-term follow-up, and that are supported with manometric measurements.

\section{Ethics}

Ethics Committee Approval: This study was approved by Van Yüzüncü Yıl University, Clinical Trials Ethics Committee.

Informed Consent: A written informed consent about the risks of the study was obtained from all patients.

Peer-review: Externally and internally peer reviewed.

\section{Authorship Contributions}

Surgical and Medical Practices: O.A., Concept: O.A., S.M.F.A., N.S.Y., A.P., M.S.E., Design: O.A., S.M.F.A., N.S.Y., A.P., S.E.,Data Collection or Processing: O.A., S.M.F.A., Ö.G., Analysis or Interpretation: O.A., N.S.Y., A.P., S.E., Literature Search: S.M.F.A., Ö.G., Writing: O.A.

Conflict of Interest: No conflict of interest was declared by the authors.

Financial Disclosure: The authors declared that this study received no financial support.

\section{References}

1. Jonas M, Scholefield JH. Anal fissure. Gastroenterol Clin North Am 2001:30:167-181

2. Schouten WR, Briel JW, Auwerda JJ. Relationship between anal pressure and anodermal blood flow. The vascular pathogenesis of anal fissures. Dis Colon Rectum 1994:37:664-669.

3. Menteş B, Leventoğlu S. Anal fissür. In: Menteş B, Bulut T, Alabaz O, Leventoğlu S, eds. Anorektal Bölgenin Selim Hastalıkları. TSCRS Society, Ankara. 2011:37-47.

4. Dunn KMB, Rothenberg DA. Colon, rectum and anus, 10th ed. In: Brunicardi FC, ed. Schwartz's Principles of Surgery. New York; McGrawHill Education,. 2014:1175-1239.
5. Pernikoff BJ, Eisenstat TE, Rubin RJ, Oliver GC, Salvati EP. Reappraisal of partial lateral internal sphincterotomy. Dis Colon Rectum 1994;37:12911295.

6. Suvarna R, Hanumanthappa MB, Panchami Rai DG. Topical diltiazem versus topical glyceryl trinitrate (GTN) in the treatment of chronic anal fissure: prospective study. Int J Biol Med Res 2012;3:1747-1750.

7. Katsinelos P, Kountouras J, Paroutoglou G, Beltsis A, Chatzimavroudis G, Zavos C, Katsinelos T, Papaziogas B. Aggressive treatment of acute anal fissure with $0.5 \%$ nifedipine ointment prevents its evolution to chronicity. World J Gastroenterol 2006;12:6203-6206.

8. Bacher H, Mischinger HJ, Werkgartner G, Cerwenka H, El-Shabrawi A, Pfeifer J, Schweiger W. Local nitroglycerin for treatment of anal fissüres: an alternative to lateral sphincterotomy. Dis Colon Rectum 1997;40:840-845.

9. Nelson RA. Systematic review of medical therapy for anal fissure. Dis Colon Rectum 2004:47:422-431

10. Cook TA, Humphreys MS, Mortensen NJ. Oral Nifedipine Reduces Resting Anal Pressure and Heals Chronic Anal fissure. Br J Surg 1999;86:12691273.

11. Drossman DA, Hasler WL. Rome IV-functional GI disorders: disorders of gut-brain interaction. Gastroenterology 2016;150:1257-1261.

12. Schouten WR, Briel JW, Auwerda JJ, De Graaf EJ. Ischaemic nature of anal fissure. Br J Surg 1996;83:63-65.

13. Utzig MJ, Kroesen AJ, Buhr HJ. Concepts in pathogenesis and treatment of chronic anal fissure: a review of the literature. J Gastroenterol 2003:98:968974.

14. Lund JN, Scholefield JH. Aetiology and treatment of anal fissure. Br J Surg 1996;83:1335-1344.

15. Klosterhalfen B, Vogel P, Rixen H, Mittermayer C. Topography of the inferior rectal artery: A possible cause of chronic, primary anal fissure. Dis Colon Rectum 1989;32:43-52.

16. Golfam F, Golfam P, Golfam B, Pahlevani P. Comparison of topical nifedipine with oral nifedipine for treatment of anal fissure: a randomized controlled trial. Iran Red Crescent Med J 2014;16:e13592.

17. Hananel N, Gordon PH. Re-examination of clinical manifestations and response to therapy of fissure-in-ano. Dis Colon Rectum 1997;40:229-233.

18. Tauro LF, Shindhe VV, Aithala PS, Martis JJ, Shenoy HD. Comparative study of glyceryl trinitrate ointment versus surgical management of chronic anal fissure. Indian J Surg 2011;73:268-277.

19. Sanei B, Mahmoodieh M, Masoudpour H. Comparison of topical glyceryl trinitrate with diltiazem ointment for the treatment of chronic anal fissure: a randomized clinical trial. Acta Chir Belg 2009;109:727-730.

20. Khan MS, Akbar I, Zeb J, Ahmad S, Khan A. Outcome of $0.2 \%$ glyceryltrinitrate cream versus $2 \%$ diltiazem cream in the treatment of chronic anal fissure. J Ayub Med Coll Abbottabad 2017;29:280-284.

21. Shrestha SK, Thapa PB, Maharjan DK, Tamang TY. Effectiveness of $0.2 \%$ glyceryl trinitrate and $0.5 \%$ nifedipine in the treatment of chronic anal fissure. JNMA J Nepal Med Assoc. 2017;56:149-152.

22. Golfam F, Golfam P, Khalaj A, Sayed MS. The effect of topical nifedipine in treatment of chronic anal fissure. Acta Med Iran 2010;48:295-299.

23. Carapeti EA, Kamm MA, McDonald PJ, Chadwick SJ, Melville D, Phillips RK. Randomized controlled trial shows that glyceryl trinitrate heals anal fissures, higher doses are not more effective, and there is a high recurrence rate. Gut 1999:44:727-730

24. Evans J, Luck A, Hewett P. Glyceryl trinitrate vs. lateral sphincterotomy for chronic anal fissure: prospective randomized trial. Dis Colon Rectum 2001;44:93-97.

25. Scholefield JH, Bock JU, Marla B, Richter HJ, Athanasiadis S, Pröls M, Herold A. A dose finding study with $0.1 \%, 0.2 \%$, and $0.4 \%$ glyceryl trinitrate ointment in patients with chronic anal fissures. Gut 2003;52:264-269. 
26. Bailey HR, Beck DE, Billingham RP, Binderow SR, Gottesman L, Hull TL, Larach SW, Margolin DA, Milsom JW, Potenti FM, Rafferty JF, Riff DS, Sands LR, Senagore A, Stamos MJ, Yee LF, Young-Fadok TM, Gibbons RD, Fissure Study Group. A study to determine the nitroglycerin ointment dose and dosing interval that best promote the healing of chronic anal fissures. Dis Colon Rectum 2002;45:1192-1199.

27. Jonas M, Neal KR, Abercrombie JF, Scholefield JH. A randomized trial of oral vs. topical diltiazem for chronic anal fissures. Dis Colon Rectum 2001;44:1074-1078.

28. Sahebally SM, Ahmed K, Cerneveciute R, Iqbal A, Walsh SR, Joyce MR. Oral versus topical calcium channel blockers for chronic anal fissure-a systematic review and meta-analysis of randomized controlled trials. Int J Surg 2017;44:87-93.

29. Cook TA, Brading AF, Mortensen NJ. Effects of nifedipine on anorectal smooth muscle in vitro. Dis Colon Rectum 1999;42:782-787.
30. Oshiro H, Kobayashi I, Kim D, Takenaka H, Hobson RW 2nd, Duran WN. L-type calcium channel blockers modulate the microvascular hyperpermeability induced by platelet-activating factor in vivo. J Vasc Surg 1995;22:732-739

31. Fleischmann JD, Huntley HN, Shingleton WB, Wentworth DB. Clinical and Immunological response to nifedipine for the treatment of interstitial cystitis. J Urol 1991;146:1235-1239.

32. Perrotti P, Bove A, Antropoli C, Molino D, Antropoli M, Balzano A, De Stefano G, Attena F. Topical nifedipine with lidocaine ointment vs. active control for treatment of chronic anal fissure: results of a prospective, randomized, double-blind study. Dis Colon Rectum 2002;45:1468-1475.

33. Ezri T, Susmallian S. Topical nifedipine vs. topical glyceryl trinitrate for treatment of chronic anal fissure. Dis Colon Rectum 2003;46:805-808.

34. Mustafa NA, Cengiz S, Türkyilmaz S, Yücel Y. Comparison of topical glyceryl trinitrate ointment and oral nifedipine in the treatment of chronic anal fissure. Acta Chir Belg 2006;106:55-58. 